\title{
MAIN FEATURES OF PREDICTION THE HYDROCARBON ACCUMULATION OF SEDIMENTARY AND BASEMENT ROCKS ON IMPACT STRUCTURES WITH STAGR TECHNOLOGY
}

\author{
I.D. Bagriy'1, M.Y. Griga² \\ (Recommended by academician of NAS of Ukraine P.F. Gozhik) \\ ${ }^{1}$ Institute of Geological Sciences of NAS of Ukraine, Kyiv, Ukraine, E-mail bagrid@ukr.net \\ Doctor of geological sciences, senior research worker, deputy of director, manager of department \\ of geological and searching researches. \\ ${ }^{2}$ Institute of Geological Sciences of NAS of Ukraine, Kyiv, Ukraine, E-mail griega@ukr.net \\ Post-graduate.
}

Main features of prediction the hydrocarbon accumulation of sedimentary and basement rocks on impact structures with STAGR technology have been presented. Main features of distribution and presence sources of oil-and-gas content on impact structures have been determined. The conclusions of oil and gas content on Boltish, Obolon, Rotmistrovka and Zeleny Gay impact structures have been presented.

Key words: impact structure, oil and gas, prediction.

\section{ОСОБАИВОСТІ ПРОГНОЗУВАННЯ ПОКАААІВ ВУГАЕВОАНІВ ОСААОВОГО ЧОХАА ТА КРИСТААІЧНИХ ПОРІА IMПАКТНИХ СТРУКТУР ЗА ТЕХНОАОГІЕЮ СТАГА}

\author{
І.Д. Багрій${ }^{1}$, М.Ю. Грига² \\ (Рекомендовано акад. НАН України П.Ф. Гожиком)
}
${ }^{1}$ Iнститут геологічних наук НАН Украӥни, Київ, Україна, E-mail bagrid@ukr.net Доктор геологічних наук, старший науковий співробітник, заступник директора, завідувач відділу геоекології та пошукових досліджень.
${ }^{2}$ Інститут геологічних наук НАН Украӥни, Київ, Україна, E-mail griega@ukr.net Аспірант.

Представлена адаптація методики структурно-термо-атмогеохімічних досліджень (СТАГД) до пошуку та прогнозування покладів вуглеводнів імпактних структур. Визначені основні особливості джерел пошерення та проявів нафтогазоносності імпактних структр. Розглянуті особливості прогнозування покладів вуглеводнів на Оболонській, Болтишівській, Ротмістрівській та Зеленогайській астроблемах.

Ключові слова: імпактна структра, прогнозування покладів вуглеводнів, нафтогазоносність.

(I.D. Bagriy, M.Y. Griga, 2015 


\title{
ОСОБЕННОСТИ ПРОГНОЗИРОВАНИЯ ЗААЕЖЕЙ УГАЕВОАОРОАОВ ОСААОЧНОГО ЧЕХАА И КРИСТАААИЧЕСКИХ ПОРОА ИМПАКТНЫХ СТРУКТУР ТЕХНОАОГИЕЙ СТАГИ
}

\author{
И.Д. Багрий ${ }^{1}$ М.Ю. Грига ${ }^{2}$ \\ (Рекомендовано акад. НАН Украины П.Ф. Гожиком)
}

\begin{abstract}
${ }^{1}$ Институт геологических наук НАН Украины, Киев, Украина, E-mail bagrid@ukr.net Доктор геологических наук, старший научный сотрудник, заместитель директора, заведуюший отделом геоэкологии и поисковых исследований.

${ }^{2}$ Институт геологических наук НАН Украины, Киев, Украина, E-mail griega@ukr.net Аспирант.
\end{abstract}

Представлена адаптация методики структурно-термо-атмогеохимических исследований (СТАГИ) к поиску и прогнозированию залежей углеводородов импактных структур. Определены основные особенности источников распространения и проявления нефтегазоносности астроблем. Рассмотрены особенности прогнозирования залежей углеводородов Оболонской, Болтышской, Ротмистровской и Зеленогайской астроблем.

Ключевые слова: импактная структура, прогнозирование залежей углеводородов, нефтегазоносность.

\section{Introduction}

Hydrocarbons exploration is associated with significant time and financial expenditures. Even drilling of exploration well could not always provide clear answer on the question regarding the practicability of further geological exploration works. Especially it is shown on the unconventional oil and gas fields like impact structures. The application of standard exploration methodologies is limited due to certain prospective constraints. The STAGR is the one technology except of drilling which obtain the information of prediction of fractured zones with increased hydrocarbon gas permeability, tectonic activity (fractured and deconsolidation zones), and geothermal gradients aimed at the solution of geological and exploration tasks and prospecting of hydrocarbon accumulation.

Interest of hydrocarbon searching on impact structures the interest has grown greatly during the last ten years. Considerable extent of hydrocarbon accumulation on Ukrainian impact structures similar to structures of Middle East, Canada and US is predicted. This article is showed main features of searching and predicting the hydrocarbon accumulation on the impact structures with STAGR technology.

\section{Target of research}

The complex of methods were used to explore the occurrence of oil-and-gas content on Boltish, Obolon, Rotmistrovka and Zeleny Gay impact structures. They all are situated in the Ukrainian Shield. Boltish and Obolon are complex structures with the central uplift, while the Rotmistrovka and Zeleny Gay are simple craters.

The Boltish impact structure is $24 \mathrm{~km}$ in diameter. It is located in the central part of the Ukrainian Shield in the Tyasmin river basin. The crater was formed in the crystalline basement rocks, mainly granites and gneisses. Impact melt rocks, suevites and allochthonous breccias fill the impact structure. The crater is surrounded by the partly eroded ejecta layer occurring in the area of about $6500 \mathrm{~km}^{2}$. The Obolon crater is a complex impact structures, about $18 \mathrm{~km}$ in diameter, located in the north-western part on the shield near its margin with Dniper-Donets Basin. The crater targets were the crystalline basement rocks and overlapping sedimentary rocks of the Late Paleozoic and Mesozoic. Now the structure is buried over $500 \mathrm{~m}$. Location of the structure near the margin of the oil and gas bearing Dnieper-Donets Basin enables to suggest its hydrocarbon potential. 
The Rotmistrovka crater is $3 \mathrm{~km}$ in diameter and $300 \mathrm{~m}$ depth. The crater is situated in the central part of the Ukrainian Shield. Suevites and lithic breccias in crater are covered by sedimentary rocks of the Cretaceous. The overlapping sedimentary rocks are clayish shale's. The Zeleny Gay crater is about $2 \mathrm{~km}$ in diameter. It is located in the central part of the Ukrainian Shield in the Ingulets river basin. The crater was formed in the crystalline basement rocks, mainly granites and gneisses. The overlapping sedimentary rocks are clays and clayish soil [Гуров, 2006].

\section{Research method}

Complex express and low-cost technology of structural thermo-atmo-geochemical research STAGR (Fig. 1) is based on a number of scientific studies in different areas performed by applying the hi-tech results of geologic, structural tectonic, geophysical, aerospace, geothermic, hydro-morphometric and gas-chemical research works, which included the design of special hi tech equipment. Special patented equipment was designed and manufactured for the conduction of atom-geochemical and thermometric plotting during the field works. STAGR methodology is patented technique [Багрій, 2009]. It was used on 80 oil and gas prospective areas with the resulting coefficient of exploration success near $100 \%$.

Advanced laboratories were established in the Institute of Geological Sciences of NAS of Ukraine, namely the gas-chemical and chromatographic laboratory (chromatographic analysis of hydrocarbons, $\mathrm{He}, \mathrm{H}_{2}, \mathrm{CO}_{2}$, ), engineering and analytic laboratory (design of equipment complexes), radiometric measurements (radon-thoron measurements), and thermo-complexes.

Application of STAGR methodologies helps to obtain important additional information during the hydrocarbons exploration:

- prediction and evaluation of the structures prospective for hydrocarbons production;

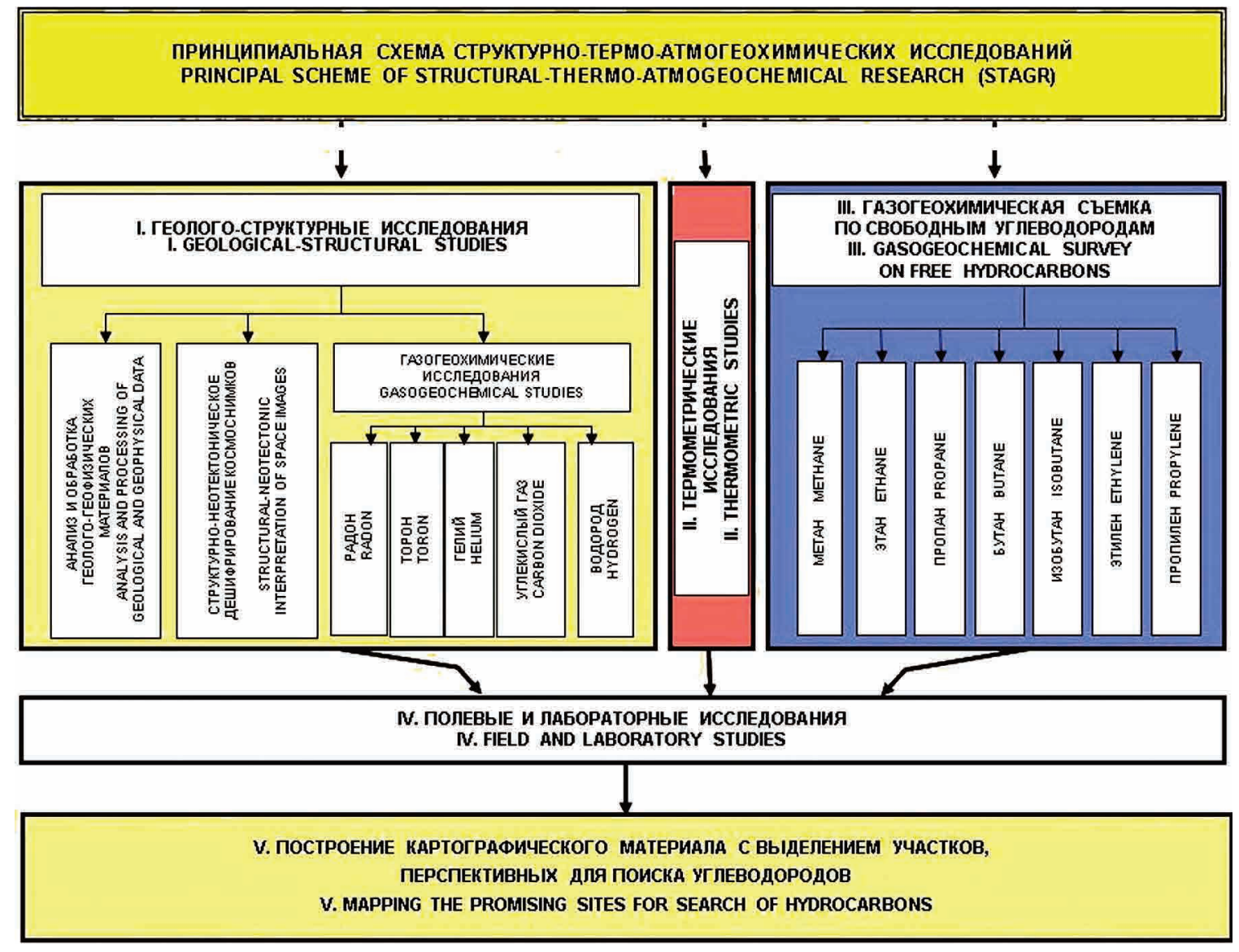

Fig. 1. Principal scheme of structural-thermo-atmogeochemical research (STAGR) 
- specification of the extraction works block structure and identification of the boundaries of productive hydrocarbons deposit;

- scientific substantiation of priority blocks for hydrocarbon exploration works and the order of exploration drilling on these blocks.

Geological-structural studies based on an analysis of available geological and geophysical data and aimed to specify the geological structure and structural-tectonic position of areas under investigation accounting the recent geodynamic features of tectonic dislocations and their manifestation in the sedimentary cover and relief. Geological structural studies are conducted with the aim of system- atization and grading of fractured block structures, permeability of tectonically active zones, seismometric, stratigraphycal and geodynamic characteristics, development of geological models for separate objects and for studied polygons.

Morphostructural analysis and structural neo-tectonic interpretation of space images and aero photo images foresees identification of neo-tectonically active faults based on their consistent association with certain types of modern structures and topographical forms using structural analysis of landscape and geomorphological specifics of current land surface employing top sheets analysis and interpretation of space and aero images (Fig. 2).

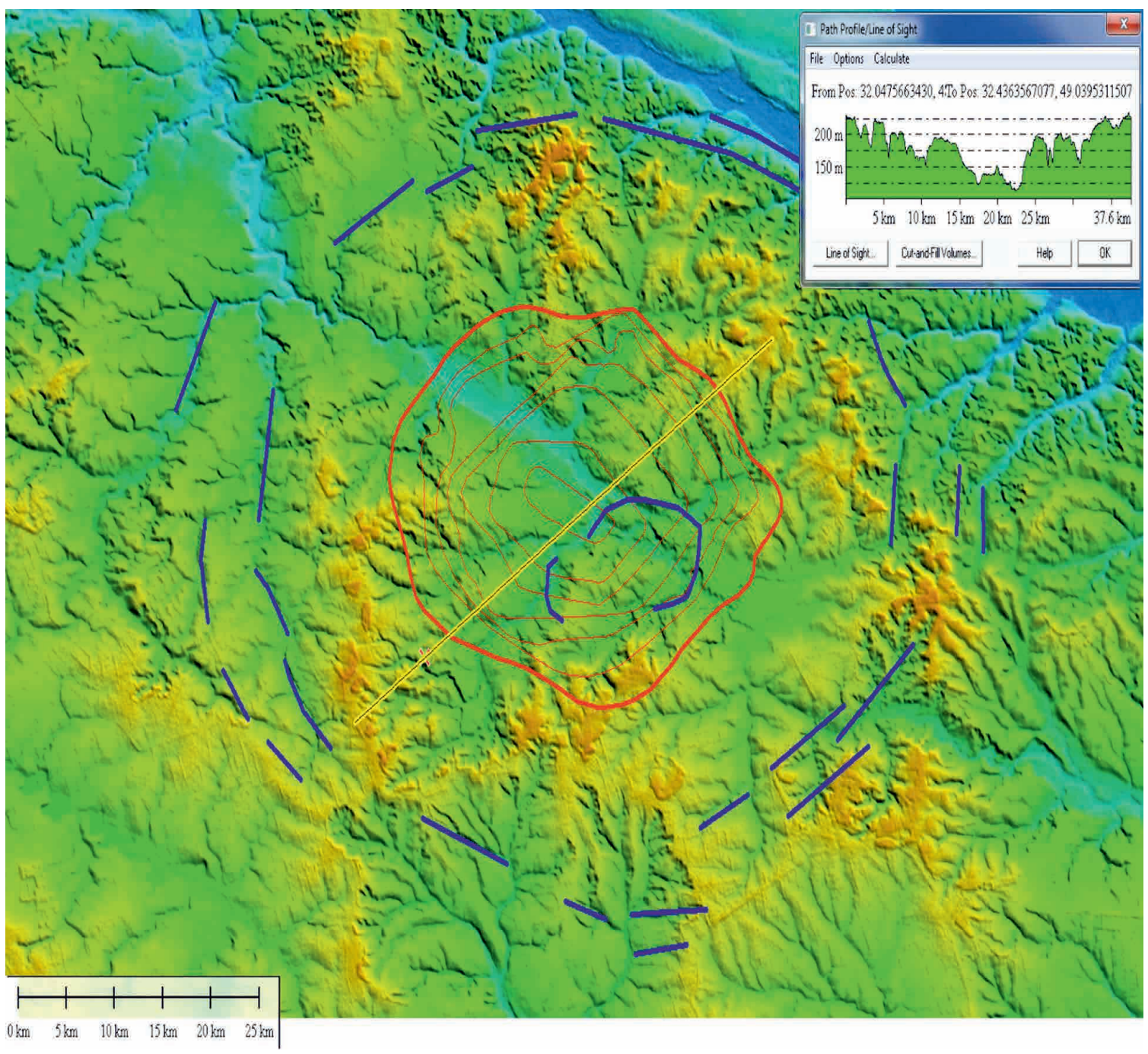

Fig. 2. The map of relief on Boltish impact structure 
Gas chemical studies are used for mapping of neo-tectonically active and permeable fractured zones [Багрій, 2005]:

- Emanation surveys (radon, thoron) are performed for mapping of neo-tectonically active fractured zones.

- Carbon dioxide gas survey. Anomalies indicate rock permeability on the studied area.

- Helium gas survey. Formation of helium anomalies in near surface conditions is caused by ascending fluid and mass flows (through fractures).

- Hydrogen gas survey. Hydrogen is an indicator of fractures depth. Hydrogen is common for detachment faults and is not found in compression zones.

Gas chemical studies of free hydrocarbons contents are based. They are provided the obvious indices presence of oil-and-gas on the exploration polygons [Багрій, 2003; Багрій, 2005].

Thermometric studies are carried out for recognition of relations of local geothermic anomalies with oil and gas accumulations in the sedimentary cover.

Mathematical and statistical studies are carried out for recognition of the informational content of each of data and group of data registries during the expedition and laboratory STAGR works. They are included Pearson correlation analysis (Fig. 3), factor analysis, anomalous field of gas contents analysis and mapping the promising sites for search of hydrocarbons.
The forecast of hydrocarbon accumulation is the result of all complexes of exploration methods. Distribution resulting maps are presented (Fig. 4-6). They are included:

- estimation of the general perspective for the exploration area on hydrocarbons,

- identification of the boundaries of deposit,

- determining the locations of unloading of hydrocarbons on earth surface, permeable zones and temperature high flow.

\section{Conclusions}

1. STAGR methodology can be successfully used for searching and prospecting of hydrocarbon accumulations on the impact structures. STAGR methodology differs from other methods of near surface exploration studies due to the following:

- scientific and methodological substantiation of the criteria for evaluation the prospectivity of studied areas allowing zoning of studied territories based on their anticipated prospectivity;

- substantiated optimal complex of express methods, providing sufficient information value of the results, fast field and laboratory analytical researches and comparatively low cost of works;

- performance of areal thermometric, emanational and gas chemical surveys;

- complex interpretation of structural, geophysical, aerospace, geological, atmogeochemical data taking into consideration

\begin{tabular}{|c|cccccccccccccccc|}
\hline $\mathrm{K}$ & $\mathrm{CH}_{4}$ & $\mathrm{C}_{2} \mathrm{H}_{8}$ & $\mathrm{C}_{2} \mathrm{H}_{4}$ & $\mathrm{C}_{3} \mathrm{H}_{3}$ & $\mathrm{iC}_{4} \mathrm{H}_{10}$ & $\mathrm{nC}_{4} \mathrm{H}_{10}$ & $\mathrm{C}_{3} \mathrm{H}_{8}$ & $\mathrm{iC}_{5} \mathrm{H}_{12}$ & $\mathrm{nC}_{6} \mathrm{H}_{12}$ & $\mathrm{C}_{8} \mathrm{H}_{14}$ & $\mathrm{CO}_{2}$ & $\mathrm{QRn}$ & $\mathrm{QTn}$ \\
\hline $\mathrm{CH}_{4}$ & 1,00 & 0,70 & 0,52 & 0,71 & 0,57 & 0,54 & 0,48 & 0,50 & 0,46 & 0,49 & $-0,40$ & $-0,34$ & $-0,41$ \\
$\mathrm{C}_{2} \mathrm{H}_{8}$ & 0,70 & 1,00 & 0,66 & 0,94 & 0,61 & 0,59 & 0,65 & 0,59 & 0,55 & 0,57 & $-0,06$ & 0,06 & $-0,08$ \\
$\mathrm{C}_{2} \mathrm{H}_{4}$ & 0,52 & 0,66 & 1,00 & 0,80 & 0,96 & 0,95 & 0,98 & 0,97 & 0,92 & 0,96 & $-0,23$ & $-0,33$ & $-0,31$ \\
$\mathrm{C}_{3} \mathrm{H}_{8}$ & 0,71 & 0,94 & 0,80 & 1,00 & 0,80 & 0,77 & 0,79 & 0,77 & 0,72 & 0,75 & $-0,09$ & $-0,07$ & $-0,15$ \\
$\mathrm{iC}_{4} \mathrm{H}_{10}$ & 0,57 & 0,61 & 0,96 & 0,80 & 1,00 & 0,99 & 0,93 & 0,98 & 0,93 & 0,96 & $-0,24$ & $-0,32$ & $-0,31$ \\
$\mathrm{nC}_{4} \mathrm{H}_{10}$ & 0,54 & 0,59 & 0,95 & 0,77 & 0,99 & 1,00 & 0,91 & 0,98 & 0,92 & 0,97 & $-0,24$ & $-0,30$ & $-0,29$ \\
$\mathrm{C}_{3} \mathrm{H}_{8}$ & 0,48 & 0,65 & 0,98 & 0,79 & 0,93 & 0,91 & 1,00 & 0,94 & 0,90 & 0,94 & $-0,23$ & $-0,32$ & $-0,28$ \\
$\mathrm{iC}_{6} \mathrm{H}_{12}$ & 0,50 & 0,59 & 0,97 & 0,77 & 0,98 & 0,98 & 0,94 & 1,00 & 0,96 & 0,99 & $-0,23$ & $-0,32$ & $-0,29$ \\
$\mathrm{nC}_{6} \mathrm{H}_{12}$ & 0,46 & 0,55 & 0,92 & 0,72 & 0,93 & 0,92 & 0,90 & 0,96 & 1,00 & 0,96 & $-0,24$ & $-0,33$ & $-0,30$ \\
$\mathrm{C}_{8} \mathrm{H}_{14}$ & 0,49 & 0,57 & 0,96 & 0,75 & 0,96 & 0,97 & 0,94 & 0,99 & 0,96 & 1,00 & $-0,20$ & $-0,31$ & $-0,29$ \\
$\mathrm{CO}_{2}$ & $-0,40$ & $-0,06$ & $-0,23$ & $-0,09$ & $-0,24$ & $-0,24$ & $-0,23$ & $-0,23$ & $-0,24$ & $-0,20$ & 1,00 & 0,46 & 0,35 \\
$\mathrm{QRn}_{n}$ & $-0,34$ & 0,06 & $-0,33$ & $-0,07$ & $-0,32$ & $-0,30$ & $-0,32$ & $-0,32$ & $-0,33$ & $-0,31$ & 0,46 & 1,00 & 0,80 \\
$\mathrm{QTn}$ & $-0,41$ & $-0,08$ & $-0,31$ & $-0,15$ & $-0,31$ & $-0,29$ & $-0,28$ & $-0,29$ & $-0,30$ & $-0,29$ & 0,35 & 0,80 & 1,00 \\
\hline
\end{tabular}

Fig. 3. The results of Pearson correlation analysis on Rotmistrovkaimpact structure. Onthe correlation matrix is shown the strong correlation coupling of gases by green color, the middle correlation coupling of gases by yellow color, the middle opposite correlation coupling of gases by red color 

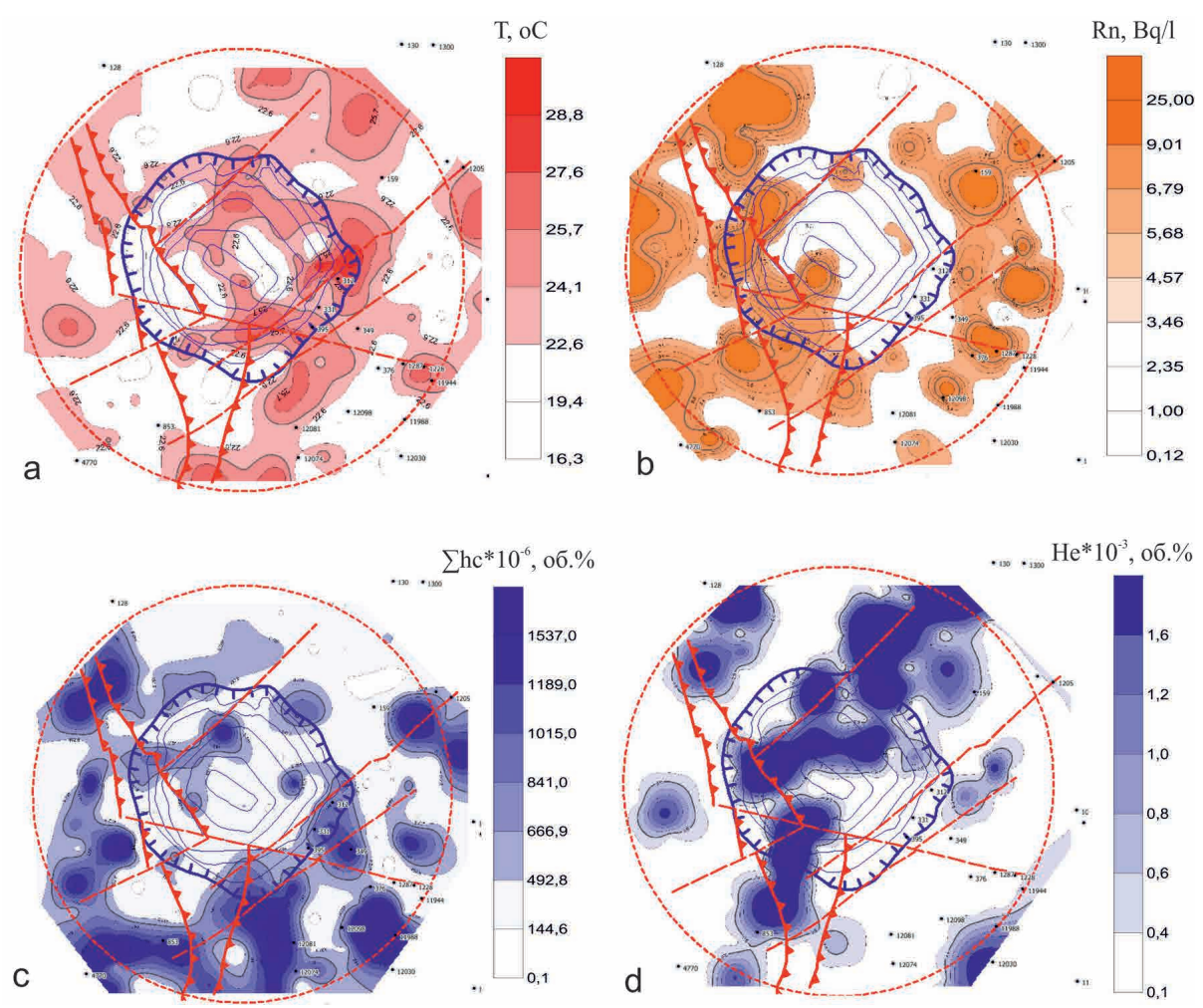

Fig. 4. Resulting maps of STAGR on Boltish impact structure: $a$ - Temperature, b - Radon, c - Sum of all registered hydrocarbons, $d$ - Helium

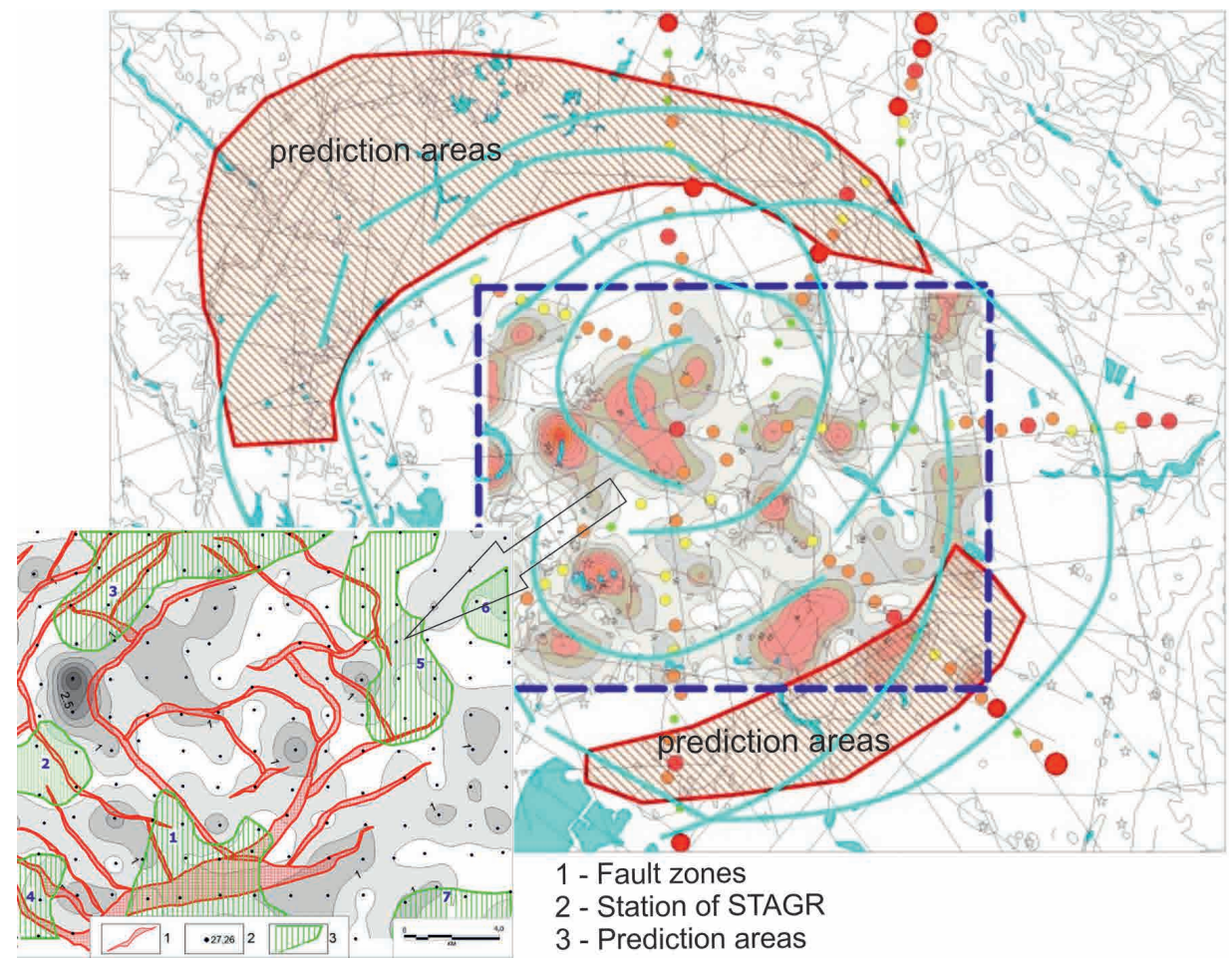

Fig. 5. Predicted areas for hydrocarbon accumulation on Obolon impact structure 

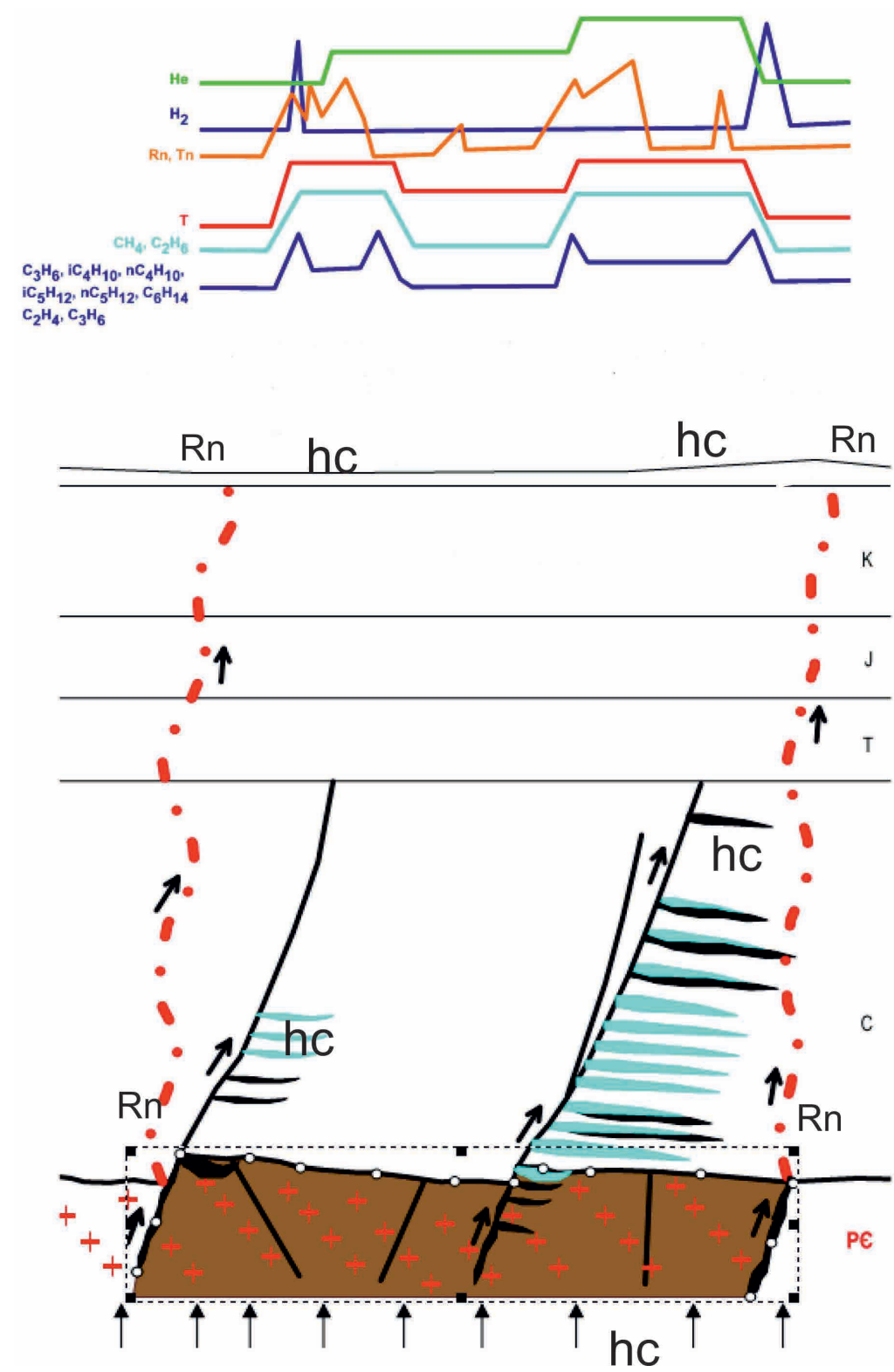

Fig. 6. The principle scheme of forming the hydrocarbon accumulation and gas-geochemical and temperature anomalies on the territory of impact structures

modern opinions on the conditions of oil and gas generation and results of geological exploration works on known deposits, which could provide initial information for development of predicting exploration models. STAGR methodology is the near surface express methods for prediction of fractured zones with increased permeability, tectonic activity (fractured and deconsolidation zones), geothermal and geochemical methods aimed at the solution of geological and exploration tasks.
2. The analysis of most characteristic features of hydrocarbon searching and prospecting on the impact structures with STAGR technology is made:

- hydrocarbon deposits are presented on the dynamically stable and low fluid permeability blocks which are conducive to formation of traps and saving hydrocarbon reservoirs in them;

- the low diffusion of scattering halos of methane and its homologues with halo-effect anomalies is presented under the prospective blocks. 
- the temperature anomalies are characterized the tipe of oil and gas presence on the prospecting areas.

3. The new approach to searching of hydrocarbon accumulation on the impact structures was made. Based on Obolon, Boltish, Rotmistrova, Seleny Gay impact structures and the complex theoretical analysis of Silian impact structure were specified main results. The deflections and the rampart areas on impact structures are of interest for searching of hydrocarbons. These areas are typically displayed in the distribution of free hydrocarbon gases as a central part of "halo-effect" anomaly with minimum values of gases in centre and maximum on the external side of the anomaly. Zones of maximum stretching and fracturing are immediately interconnected with these areas. They are presented on the sedimentary rocks as also on the basement zones of high

\section{References}

1. Багрій І.Д. Прогнозування розломних зон підвищеної проникності гірських порід для вирішення геологічних та пошукових задач. Київ: ІГН НАН Ураїни, 2003. 149 с.

Bagiy I.D., 2003. Prediction of fault zones of increased rock permeability for geoecological and searching tasks solutions. Kyiv: IGS NAS of Ukraine, 149 p. (in Ukrainian).

2. Багрій І.Д., Гладун В.В., Дубосарський В.Р., Знаменська Т.О., Клочко В.П., Лазаренко О.В., Янцевич О.О. Флюїдодинамічні ознаки Оболонської кільцевої струтури за результатами приповерхневих термометричних та атмогеохімічних досліджень. Тектоніка і стратиграфія. 2005. Вип. 34. С. 43-49.

Bagriy I.D., Gladun V.V., Dubosarsky V.R., Znemenska T.O., Klochko V.P., Lazarenko O.V., Yanzevich O.O., 2005. Fluid dynamic features of Obolon impact structure based on the results of themometic and atmo-geochemical exploration. Tectonika $i$ stratigafiya, № 34, p. 43-49 (in Ukrainian). fracturing. The presence of Helium is pointed at the presence of deep flow from PaleozoicMesozoic horizons and deeper from the earth's crust. The presence of Radon anomalies are pointed at high permeability faults. They routed fluid from basement to earth surface. Such areas are never indicated the hydrocarbon accumulations. Radon high permeability boundaries are caused the migration of underground water to the surface as also are formed the needed pressure conditions for forming tectonically near boundary fracture-pore collectors. Such areas are depended of high water exchange and are predicted as the most promising for groundwater extraction.

Interconnection of search methods to the STAGR technology is afforded a completely new idea of prediction of hydrocarbons in nontraditional geological objects named impact structures.

3. Гуров Е.П., Гожик П.Ф. Импактное кратерообразование в истории Земли. Киев, 2006. 216 c.

Gurov E.P., Gozhik P.F., 2006. Impact catering in the Eath's History. Kiev, 216 p. (in Russian).

4. Свідоцтво України № 28176 авторського права на твір «Комплесна методика (структурнотермо-атмогеохімічних досліджень (СТАГД))» / Багрій І.Д., Гожик П.Ф.; заявник і власник Інститут геологічних наук НАН Ураїни. 31.03.2009.

Patent № 28176 «A comprehensive methodology (Structual-thermo-atmogeochemical research (STAGR)» / Bagiy I. D., Gozhik P. F., applicant and owner IGS NAS of Ukraine. 31.03.2009 (in Ukrainian).

Received

November 27, 2014 